\title{
Cancer care for adolescents and young adults in Jordan
}

Hikmat Abdel-Razeq, ${ }^{1}$ Maha Barbar, ${ }^{2}$ Taher Abu Hejleh ${ }^{1}$ and Asem Mansour ${ }^{3}$

Department of Internal Medicine, King Hussein Cancer Center, Amman, Jordan (Correspondence to: H. Abdel-Razeq: habdelrazeq@khcc.jo).

${ }^{2}$ Department of Pediatrics, Hashemite University, Zarka, Jordan. ${ }^{3}$ Department of Radiology, King Hussein Cancer Center, Amman, Jordan.

\begin{abstract}
Background: Adolescents and young adults with cancer have special characteristics and needs.

Aims: This study highlighted psychosocial challenges, fertility issues and secondary diseases encountered in adolescents and young adults with cancer. This work is meant to be a platform for future interventions for cancer in this demographic.

Methods: We investigated the latest edition of the Jordan Cancer Registry (JCR) and our more comprehensive institutional database during 2000-2012. Smoking, obesity and fertility preservation were addressed briefly as important issues among AYA patients.

Results: Cancer among adolescents and young adults represents 16.3\% of all new cancer cases and has increased by $25 \%$ over the past 12 years. Women are more likely to be involved (female: male ratio of 1.44: 1) because of thyroid and breast cancers. Five-year survival rate for the AYA group was $72.4 \%$, which was significantly better than for adults aged $\geq 40$ years $(59.8 \%)$ but worse than for paediatric patients aged $<15$ years $(79.2 \%)(P<0.0001)$.
\end{abstract}

Conclusions: Cancer in adolescents and young adults represents a substantial and growing proportion of oncological diagnoses. Due to their special needs and treatment complications, a dedicated service is urgently needed.

Keywords: Cancer; Jordan; adolescents, survival, registry

Citation: Abdel-Razeq H; Barbar M; Abu Hejleh T; Mansour A. Cancer care for adolescents and young adults in Jordan. East Mediterr Health J. 2018;24(7):687-695. https://doi.org/10.26719/2018.24.7.687

Received: 23/01/17; accepted: 15/06/17

Copyright (C) World Health Organization (WHO) 2018. Some rights reserved. This work is available under the CC BY-NC-SA 3.0 IGO license (https:// creativecommons.org/licenses/by-nc-sa/3.o/igo).

\section{Introduction}

Cancer is one of the leading causes of morbidity and mortality in Jordan. Latest national mortality data showed that cancer accounts for $16.5 \%$ of all deaths, next only to cardiovascular disease, which claims more than one third (38.4\%) of the total national mortality (1).

Adult oncologists usually deal with older patients who tend to have the highest incidence of cancer, and paediatric oncologists tend to focus on younger age groups. Thus, many of the issues related to older paediatric patients and younger adults are lost in between. Ferrari et al. described this situation as: "Adolescent patients with cancer reside in a 'no-man's land' between the world of paediatric oncology and that of 'adult' medical oncology" (2). Additionally, adolescent and young adult (AYA) patients are underrepresented in clinical trials and that might explain the lack of progress in treatment outcomes in this age group $(2,3)$. The field of AYA oncology is evolving rapidly and has become a focused subspecialty.

In Jordan and many neighbouring countries, the definition of paediatric patients is inconsistent. We use 18 years of age as the cutoff at our centre, however, many hospitals and healthcare facilities, including the Ministry of Health and military and university-based hospitals in the country treat patients above the age of 13 years as adults. There is significant variation in the definition used to describe the age of the AYA cancer population. The National Comprehensive Cancer Network (NCCN)
(4) and National Cancer Institute (NCI) (5) define AYAs as 15-39 years, and as such, reported that $\sim 70$ ooo young patients are diagnosed with cancer each year in the United States of America (USA), which accounts for 5\% of all cancers diagnosed. Other researches and health organizations, including the World Health Organization (WHO) (6) and the Surveillance, Epidemiology and End Results (SEER) programme (7), use different definitions of 15-25 and 15-29 years, respectively.

Tumour biology and treatment outcomes vary among different age groups. Thus, an age-specific approach is needed when dealing with these cancers; acute leukaemia is a good example (8-10).

Fortunately, treatment outcomes in childhood and adolescent cancer tend to be significantly better compared to those in older adults. Many younger patients survive, which highlights the need for a structured survivorship programme that takes into account the many specific issues related to their cancer and its treatment-related late complications; both physical and psychosocial (11,12). This retrospective study and literature review aimed to address such specific issues. It is hoped that this work may stimulate more research in this important field, especially given that most of our population is within this younger age group.

\section{Methods}

We utilized the latest edition of the Jordan Cancer 
Registry (JCR) report published in 2012 (13). The JCR report stems from an annual population-based registry that was established in 1996 under the jurisdiction of the Ministry of Health. We identified all cancers reported by the JCR in the 15-39-year age group for the period 2000-2012. The national registry does not report treatment outcomes or survival data, so these data were collected using our own institutional cancer registry that was started in 2006. This represents $>60 \%$ of the total national cancer patients and is matched to the dataset used to generate the JCR report. The cases registered within our cancer centre had their diagnosis confirmed and all their treatment and followup in our institution.

Pubmed/Medline was searched for all published literature using the key words: Cancer; Jordan; Adolescents, Survival and Registry. Abstracts presented at major international conferences were also reviewed.

Descriptive statistics were performed for all variables. Results for continuous variables were expressed as median (interquartile range). Categorical variables were expressed as numbers (percentages). The Kaplan-Meier method was adopted to estimate overall survival (OS) curves, and a log-rank test was used to compare patients' survival times between age groups. OS was calculated from the time of primary diagnosis to death from any cause or to the last contact based on the patients' status (dead or alive). A significance level of $P \leq 0.05$ was used in the analysis. All curves were created using GraphPad Prism version 6 (La Jolla, CA, USA), and all analyses were performed using SAS version 9.4 (SAS Institute, Cary, NC, USA).

\section{Results}

A total of 5013 new cancer cases were recorded in Jordan in 2012. Median age at diagnosis was 56 years, with considerable variation according to the cancer site and sex (60 years for men and 53 years for women) (13). In 2012, the crude incidence rate of all cancers among Jordanians was 78.5 per 100000 (71.2 for men and 86.2 for women). The age-standardized rate (ASR) adjusted to the World Standard Population was 133.4 per 100 o0o population (126.1 for men and 141.4 for women) (13).

There were 815 AYAs, aged 15-39 years, diagnosed with cancer throughout Jordan in 2012. This represents $16.3 \%$ of the total number of cancer cases diagnosed during this period (Table 1). The female: male ratio was 1.44: 1. This female predominance was evident across all age subgroups and was mostly due to the high percentage of breast and thyroid cancers in women in the AYA age group.

Breast cancer, thyroid cancer and Hodgkin's lymphoma were the most common cancers in women in the AYA group, while testicular cancer, leukaemia and lymphoma were the most commonly encountered tumours among men (Figure 1).

Since the introduction of the population-based national cancer registry in 1996, the total number of reported cases of cancer has increased from 3362 in 2000
Table 1 AYA (male and female) versus all cancer cases (2012)

\begin{tabular}{lccc} 
Primary cancer & $\begin{array}{c}\text { AYA cases } \\
\text { (n) }\end{array}$ & $\begin{array}{c}\text { All cases } \\
\text { (n) }\end{array}$ & $\%$ \\
Breast & 149 & 1008 & 14.8 \\
Thyroid & 97 & 203 & 47.8 \\
HD & 68 & 109 & 62.4 \\
Leukaemia & 71 & 243 & 29.2 \\
Colorectal & 58 & 567 & 10.2 \\
Testis & 50 & 59 & 84.7 \\
NHL & 49 & 218 & 22.5 \\
Brain and CNS & 34 & 167 & 20.4 \\
Bone & 33 & 47 & 70.2 \\
Total & 815 & 5013 & 16.3 \\
\hline
\end{tabular}

HD = Hodgkin's disease NHL = non-Hodgkin's lymphoma, $\mathrm{CNS}=$ central nervous system Source: Jordan Cancer Registry, Ministry of Health, 2012.

to 5013 in 2012; a 49\% increase. A similar increase was also noted in the AYA group, albeit at a slower rate. Cancer cases have increased from 654 in 2000 to 815 in 2012; a $25 \%$ increase. Much of this increase was in the older age groups of 30-34 and 35-39 years (Figure 2). The number of cases did not increase as much in the younger age
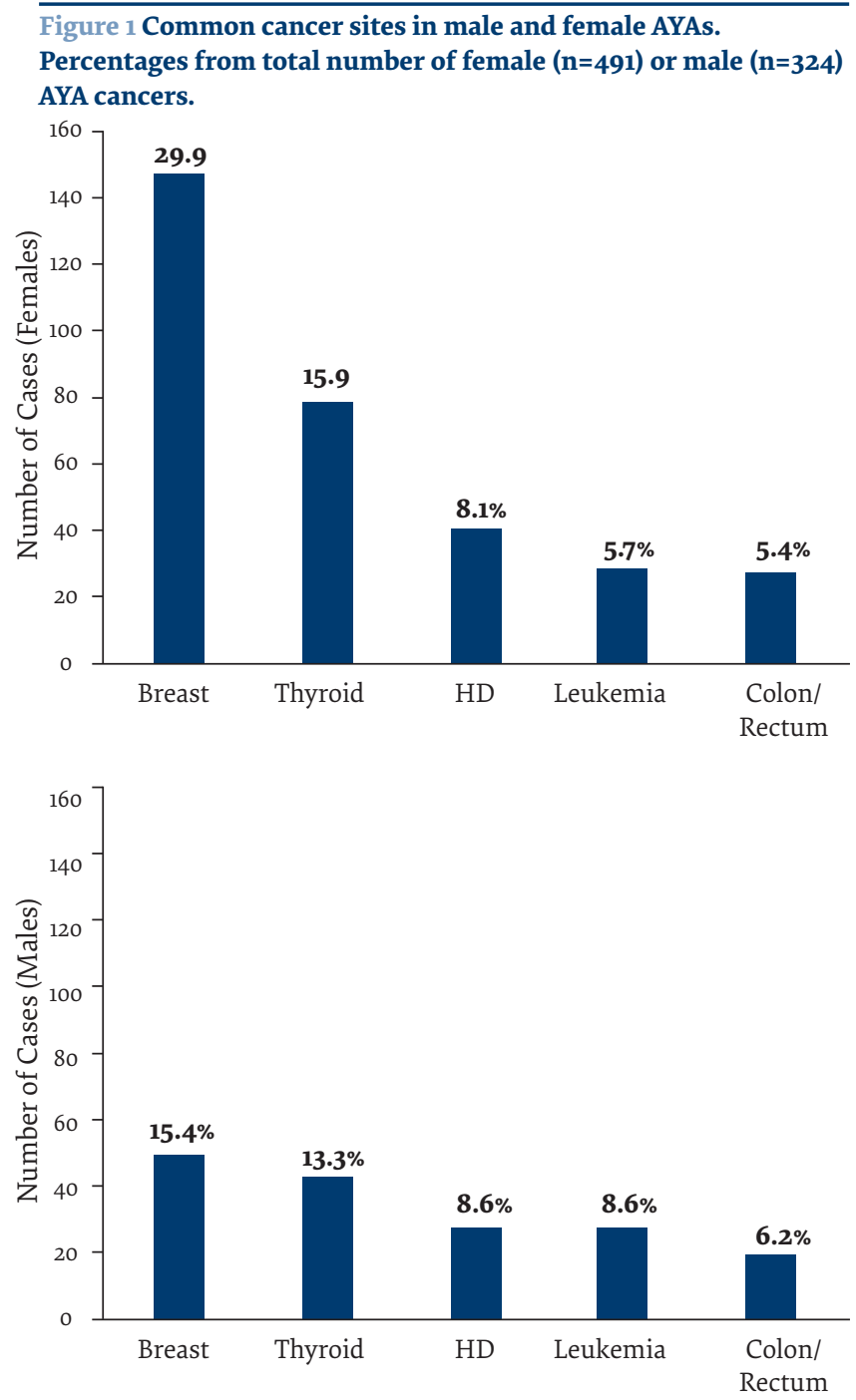
groups (15-29 years).

Survival data were available for 10328 patients; 2194 $(21.2 \%)$ of them among the AYA group (Figure 3A). All were diagnosed, treated and followed up at our institution. Five-year OS for the AYA group was $72.37 \%$, which was significantly better than for adults aged $\geq 40$ years (59.75\%) but worse than for paediatric patients aged $<15$ years $(79.18 \%)$ (log-rank test $<0.0001)$. To address further the importance of age, we grouped AYA patients into two groups (15-30 and 31-39 years). Five-year OS for the younger group was $75.48 \%$, compared to $69.93 \%$ for the older group $(P=0.0295)$ (Figure 3B).

\section{Discussion}

Survival of AYA patients with cancer is significantly better than in older age groups. Even among the AYA age group itself, patients aged $\leq 30$ years have better survival than those aged $>30$ years. Such findings can be explained by the types of cancer encountered and absence of comorbidity in this age group. A total of 4.1 million (43\%) Jordanians are within the AYA age group, which means that Jordan, like many other countries in the Eastern Mediterranean Region, can be considered to have a young population. Although the incidence of cancer in this age group is lower than in older people, many special issues are encountered in routine clinical practice that are worth highlighting.

Women are more affected than men because of breast and thyroid cancer. This highlights the importance of issues like fertility preservation among young women, and many are exposed to therapies that can negatively affect their fertility. In the following paragraphs we address issues related to breast cancer as the commonest cancer in this age group, followed by a brief discussion of late effects of childhood cancers, smoking, obesity and fertility preservation.

\section{Breast cancer}

Breast cancer remains the most common cancer among women, even in the AYA group. In Jordan and many neighbouring countries, breast cancer tends to be diagnosed at an earlier age. As reported by the JCR, the median age at diagnosis had not changed over the last 12

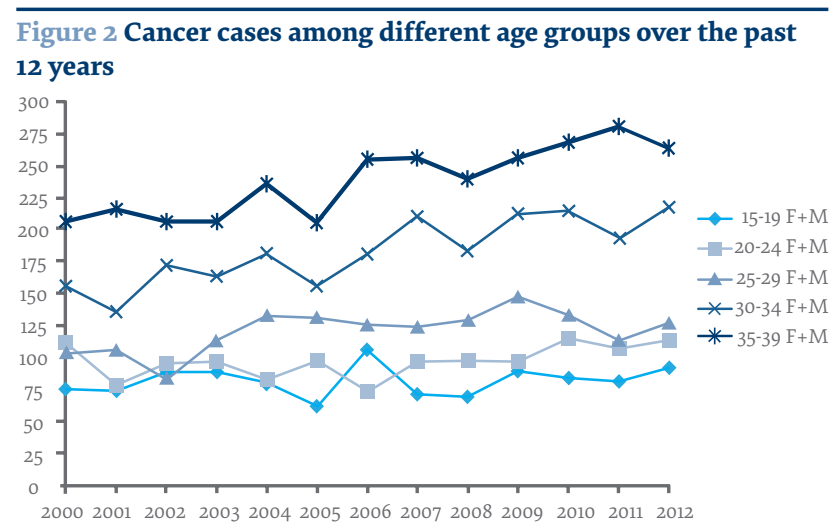

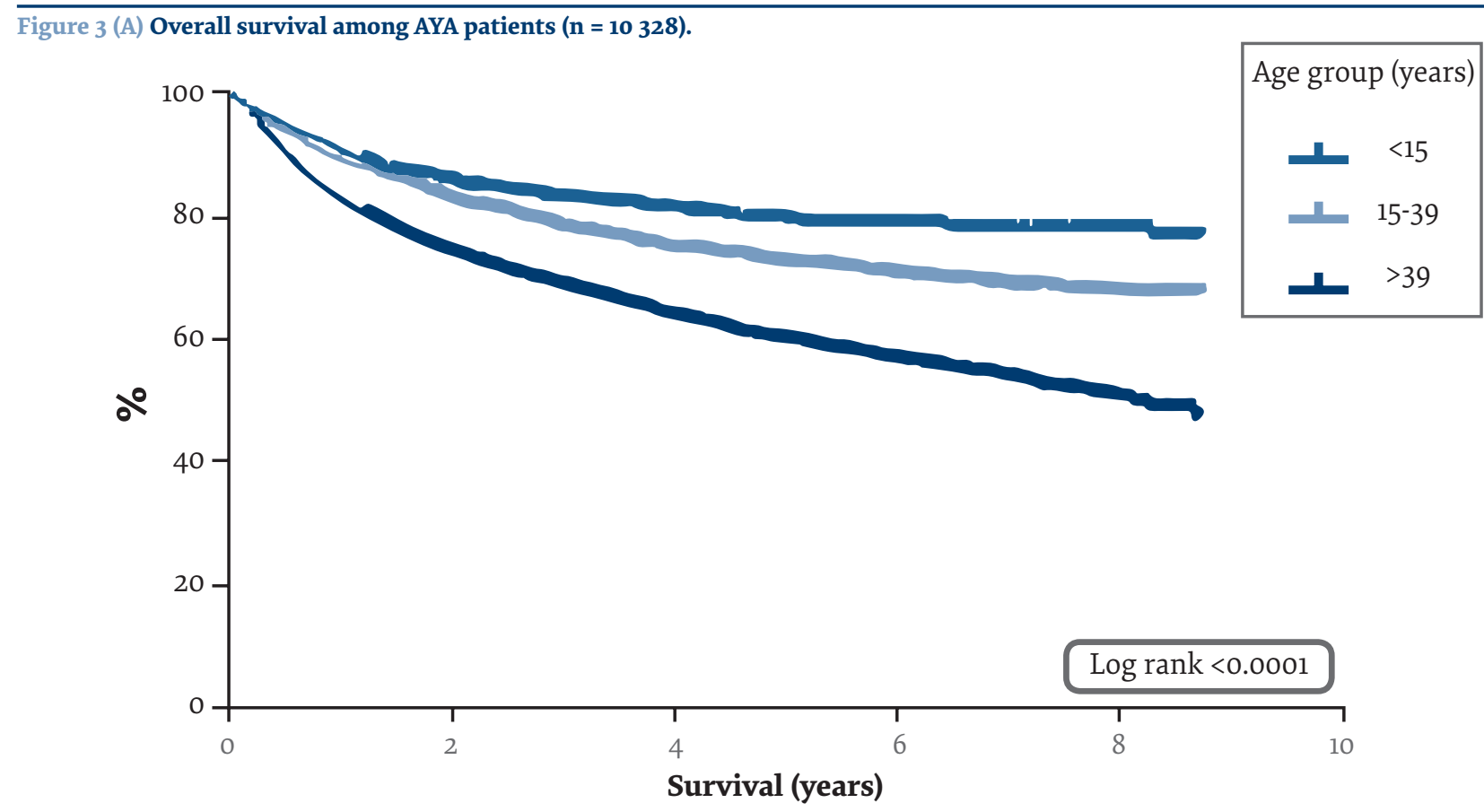

\begin{tabular}{ccccc} 
Age (years) & Subjects & Events & Censored & 5-year survival rate \\
\hline$<15$ & 1125 & 216 & 909 & $79.18 \%$ \\
$15-39$ & 2194 & 559 & 1635 & $72.37 \%$ \\
$>39$ & 7009 & 2643 & 4366 & $59.75 \%$ \\
\hline
\end{tabular}

Source: King Hussein Cancer Center Registry data (July 2006-December 2013). 
Figure 3 (B) Overall survival by age group among AYAs ( $\mathbf{n}=2194)$.

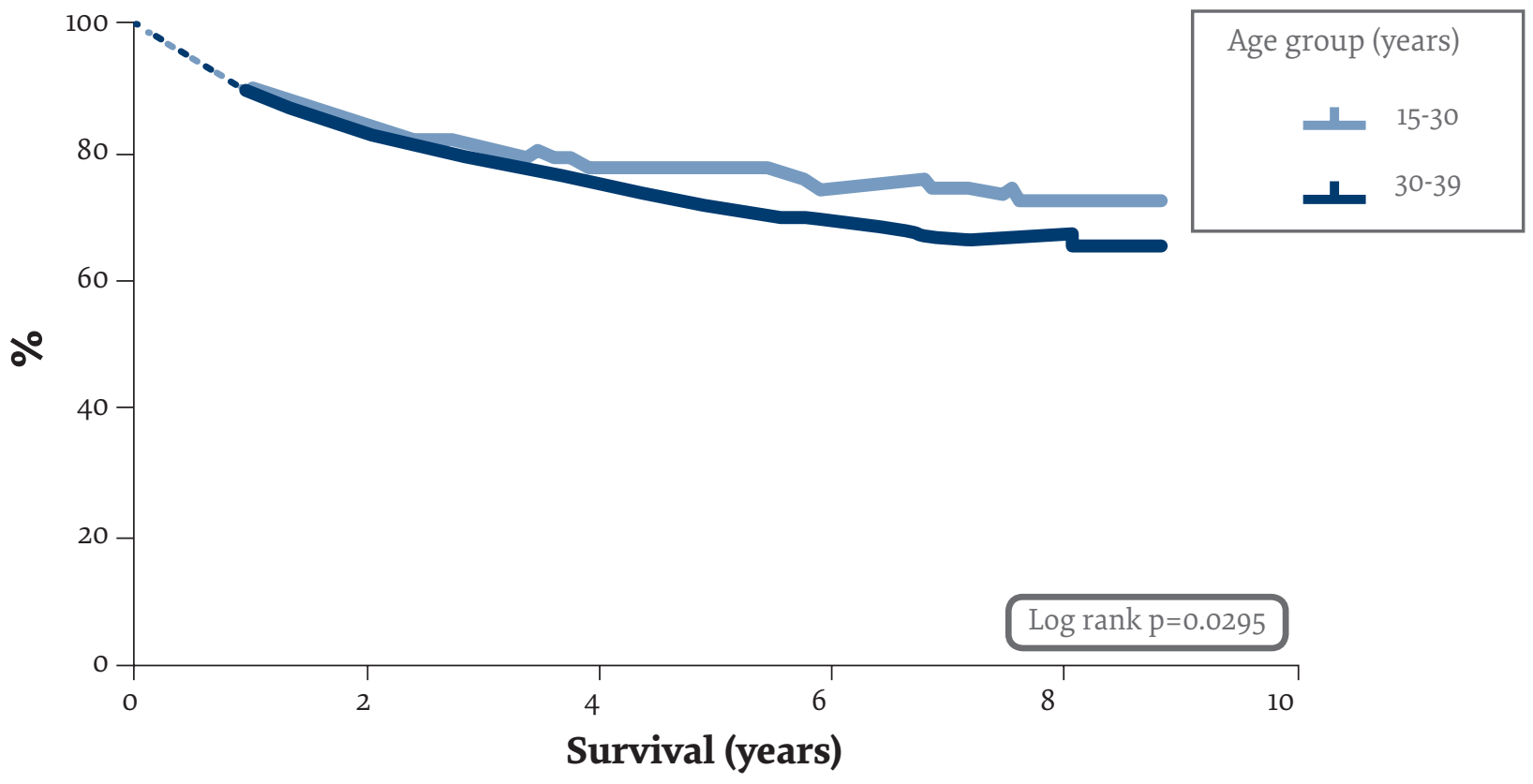

\begin{tabular}{ccccc} 
Age (years) & Subjects & Events & Censored & 5-year survival rate \\
$15-30$ & 951 & 220 & 731 & $75.48 \%$ \\
$30-39$ & 1243 & 339 & 904 & $69.93 \%$ \\
\hline
\end{tabular}

Source: King Hussein Cancer Center Registry data (July 2006-December 2013).

years and remains at 50-51 years (13). In 2012, 149 breast cancer cases were reported among AYAs, representing $18.3 \%$ of all cancers in this age group and $14.8 \%$ of all breast cancer cases. In western societies, only $7.0 \%$ of all female breast cancer is diagnosed in women aged $<40$ years (14).

Breast cancer in younger patients tends to be associated with more aggressive features (15-17), leading to poorer prognosis and a need for more aggressive treatment, which results in a higher likelihood of longterm treatment-related toxicity, and unique psychosocial concerns (18).

Additionally, familial breast cancer is more common in this age group. Over $10-15 \%$ of breast cancer patients carry high-risk mutation genes like BRCA-1 and BRCA-2 (19). Given the high penetrance rates among such mutation carriers $(20,21)$, it is important to identify patients for whom many additional risk-reduction interventions, like bilateral mastectomy and oophorectomy can be considered.

Breast reconstruction following surgery in the diseased breast or prophylactic mastectomy is important, especially in young patients. Such surgery cannot be performed without the appropriate setup that includes a multidisciplinary team approach with full psychosocial support that should also address financial cost. Most reconstructive procedures and prophylactic surgery are usually denied by almost all local private and governmental health insurance plans.

\section{Late effects of childhood cancer}

Late effects of childhood cancer treatment are well recognized and defined as adverse effects with onset $\geq 5$ years after completion of therapy. However, this problem is not sufficiently addressed in cancer care in developing countries. The Childhood Cancer Survivor Study initiated in 1994 is the main source for understanding these late effects (22). Large cohorts of survivors were collected and followed longitudinally. In its initial phase, the study included > 14000 survivors who were treated between 1970 and 1986. More recently, the study has expanded to include 10000 more survivors diagnosed between 1987 and 1999 (23). Premature menopause, stroke, and second cancers were among the common potential late effects. Childhood cancer survivors should receive close, longterm follow-up, which is not routinely available.

\section{Smoking}

The association between tobacco smoking and cancer is well established. In a study reported in 2012, approximately half $(45 \%)$ of the Jordanian population had smoked a cigarette in the past month, $40 \%$ in the past week, and $36 \%$ in past 24 hours (24). Waterpipe tobacco smoking is becoming popular in Jordan and neighbouring countries, especially among AYAs. In another study reported in 2014, 
1845 students from 4 local universities were randomly recruited. Waterpipe tobacco smoking rates were $30 \%$ in the past 30 days and 56\% ever, while cigarette smoking rates were $29 \%$ in the past 30 days and $57 \%$ ever. Past 30-day waterpipe tobacco smoking rates were $59 \%$ for men and $13 \%$ for women (25). In a third study conducted among 547 students in local dental schools, $54.3 \%$ of men and $11.1 \%$ of women reported current tobacco use. The majority had used both cigarettes and waterpipe tobacco. Nearly half of the women reported that they smoked at home in the presence of their parents (26). These findings underscore the extent of the smoking problem in our population, especially among the younger age groups, and the urgent need for effective smoking cessation interventions.

A national cancer control programme does not exist in Jordan. However, a tobacco control programme was recently established to help increase public awareness of the hazards of smoking and to introduce new legislation that prohibits smoking in public places. However, compliance with such programmes is still poor.

Although no official data exist on the smoking rates among AYA cancer survivors, it is expected to be high. The physical and psychosocial complications that result from cancer treatment places stress on patients, especially younger ones, that may encourage them to smoke, especially within a society that views smoking as a common cultural habit. This is an important issue to recognize as the late complications of AYA cancer treatment, such as coronary artery disease and stroke, are likely be higher with smoking.

\section{Obesity}

Obesity continues to represent a significant public health problem and has recently grown into a major global health epidemic (27). In the USA, more than two thirds of adults are now overweight and one third is obese. It is also estimated that one third of children and adolescents in the USA are either obese or overweight (28). In a more recent report, the prevalence of obesity among children and adolescents aged 2-19 years was $17.0 \%$ and extreme obesity was $5.8 \%$ (29). Obesity in Jordan and many neighbouring countries is also common. In a study that included 2836 subjects aged $\geq 25$ years conducted in 4 Jordanian towns, the overall prevalence of obesity, defined as body mass index $\geq 30 \mathrm{~kg} / \mathrm{m} 2$, was $49.7 \%$. Obesity was more common in women (59.8 vs $32.7 \%$ in men) (30). More recent studies have reached similar conclusions $(31,32)$.

Cancer treatment, directly or indirectly, can lead to overweight and obesity. Steroids are active components of many chemotherapeutic regimens and are widely prescribed as antiemetic therapy. Cranial irradiation for childhood cancer appears to have the greatest influence on obesity in adult life. In a study reported in $2015,47 \%$ of those who received this form of treatment became obese compared with $29.4 \%$ who did not (33). A retrospective study in 2003 compared 1765 adult survivors of childhood acute lymphoblastic leukaemia, whose treatment protocol included cranial irradiation, to 2565 adult siblings of childhood cancer survivors (34). The odds ratio for being obese in survivors in comparison with siblings was 2.59 for women and 1.86 for men. The risk of obesity was greatest among women diagnosed at $0-4$ years of age and treated with radiation doses $\geq 20 \mathrm{~Gy}$.

Even in children and adolescents, obesity is associated with many comorbidities including gastrointestinal, endocrine, cardiovascular, orthopaedic, pulmonary, neurological, dermatological and psychosocial problems (35). In addition to these serious medical problems, direct medical cost and economic impact related to obesity and its associated problems put a lot of pressure on healthcare budgets (36).

Many large epidemiological studies have clearly shown that obesity is a major modifiable risk factor for many cancers including, but not limited to, cancer of the endometrium, colorectum, kidney, oesophagus, breast and pancreas (37-40). Moreover, obesity can be a poor prognostic factor and contributes to the unfavourable survival rates in obese patients with cancer (38,41-43). Higher likelihood of comorbidity and unfavourable tumour characteristics and a tendency to underdose chemotherapy in obese patients may contribute to such poorer survival rates, particularly among breast cancer patients $(44,45)$. With the earlier onset of overweight and obesity, often occurring during childhood, there is a concern that the effects of obesity on cancer outcomes are even worse. Although we do not have strong evidence that weight loss is associated with better cancer survival, improved diet and greater physical activity associated with weight loss do have clear health advantages.

Given the above problems, there is an urgent need to implement health programmes to prevent and control overweight and obesity at a national level (46). Counselling with a dietician and establishment of an exercise programme should be routine components of the multidisciplinary approach to cancer. Oncologists should devote enough time to discuss weight loss with their overweight patients with cancer (47).

\section{Fertility preservation}

Over recent decades, survival rates for most cancers have significantly improved and more younger patients survive their disease. Many of the cancer treatment methods, especially chemotherapy, can have a negative impact on fertility both in men and women. There are established means of preserving fertility prior to cancer therapy. Sperm cryopreservation is routinely practiced in young men and in vitro fertilization and embryo cryopreservation are widely available for young women. Several innovative techniques, including ovarian tissue cryopreservation, are being actively investigated. Current techniques are limited by the patient's sexual immaturity, and all available approaches for children are experimental $(48,49)$. Several studies have shown that gonadotropin-releasing hormone agonists when used with chemotherapy protect against ovarian failure, reducing the risk of early menopause and improving prospects for fertility (50). 
Several factors may contribute to low compliance rates. Impaired future fertility is difficult for children to understand although outcomes are potentially traumatic to them as adults (51). Additionally, patients may not be aware of the potential fertility loss and such problems may not be communicated well by the treating physicians (51, 52). Patients and families are usually overwhelmed and focus exclusively on the cancer diagnosis and treatment and may be concerned that pursuing fertility preservation will delay their treatment, thus negatively affecting their cure rates (53-55). In a web-based survey from the DanaFarber Cancer Institute, Boston, USA, in 2010, only $29 \%$ of 657 breast cancer patients with a mean age at diagnosis of 32.9 years reported that infertility concerns influenced their treatment decisions (56). In 2013, the American Society of Clinical Oncology (ASCO) issued updated guidelines recommending that providers discuss fertility preservation with all patients of reproductive age who will be receiving cancer treatment with a possible risk of iatrogenic infertility. However, compliance with such recommendations is still poor, even in western societies (57). In another study, 201 patients aged 13-50 years who received a new cancer diagnosis and planned to initiate curative chemotherapy at the University of North Carolina were reviewed (58). Only $59(29 \%)$ received fertility counselling and $23(11 \%)$ attempted sperm banking. Younger patients were significantly more likely to be counselled, with mean ages of 27.4 and 40.4 years for counselled and noncounselled patients, respectively. Among counselled patients, those with a lower median income or who had Medicaid or no insurance were less likely to bank sperm.

The present study and many others (59-61) clearly demonstrate the low referral rates for fertility counselling and fertility preservation. Improved education for providers, system-wide interventions, implementing standardized processes for sperm and ova preservation, and the institution of fertility preservation programmes will hopefully increase referral for such services.

\section{Conclusion}

More than $40 \%$ of the Jordanian population are within the AYA age group. Fortunately, the cancer incidence in this age group is lower and their survival is better than in older adults. Smoking, obesity and fertility preservation are among many other important issues in this age group. Specialized ancillary services addressing these issues need to be incorporated into multidisciplinary teams treating such patients, leading to the establishment of comprehensive AYA cancer programmes.

\section{Funding: None.}

Competing interests: None declared.

\section{Soins du cancer chez l'adolescent et le jeune adulte en Jordanie}

\section{Résumé}

Contexte : Les caractéristiques et les besoins particuliers des adolescents et des jeunes adultes atteints de cancer sont spécifiques.

Objectif : La présente étude a mis en évidence les difficultés psychosociales, les questions liées à fécondité et les pathologies secondaires auxquelles font face les adolescents et les jeunes adultes atteints de cancer. Ce travail a été conçu pour servir de tremplin à de futures interventions en faveur d'un traitement anticancéreux destiné à cette tranche de population.

Méthodes: De 2000 à 2012, nous avons basé notre étude sur la dernière édition du Registre national du cancer de Jordanie, ainsi que sur notre base de données institutionnelle, plus complète. Les questions liées au tabagisme, à l'obésité et à la préservation de la fécondité chez les patients appartenant au groupe des adolescents et des jeunes adultes ont été brièvement traitées et considérées comme des problèmes importants.

Résultats : Le cancer des adolescents et des jeunes adultes représente $16,3 \%$ de tous les nouveaux cas de cancer et cette proportion a augmenté de $25 \%$ ces 12 dernières années. Le risque d'atteinte est plus élevé chez les femmes (le ratio femmeshommes étant de $1,44: 1$ ) en raison des cancers de la thyroïde et du sein. Le taux de survie à cinq ans pour le groupe des adolescents et des jeunes adultes était de 72,4\%, taux significativement plus élevé que celui présenté par les adultes de 40 ans et plus (59,8\%), mais moins favorable que celui des patients pédiatriques de moins de 15 ans $(79,2 \%)(p<0,0001)$.

Conclusion : Le cancer des adolescents et des jeunes adultes représente une part notable et croissante des diagnostics oncologiques. Étant donné qu'il implique des besoins et des complications de traitement particuliers, il est urgent de créer un service consacré à cette tranche de population. 


\section{رعاية مرضى السرطان المر اهقين والشباب في الأردن \\ حكمت عبد الرزاق، مها بربر، طاهر أبو حجلة، عاصم منصور

$$
\text { الخلفية: للمر اهقين و الشباب المصابين بالسر طان خصائص متميزة واحتياجات خاصة. }
$$

الهدف: أبرزت هذه الدراسة التحديات النفسية والاجتماعية وقضايا الخصوبة والأمراض الثانوية التي يواجهها المراهقون والشباب المصابون

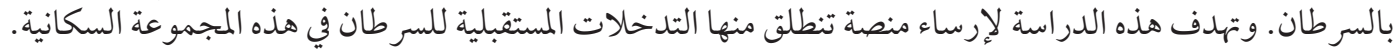

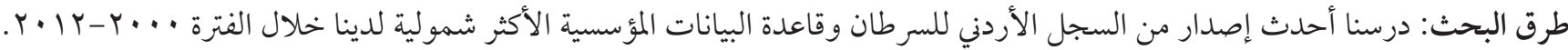

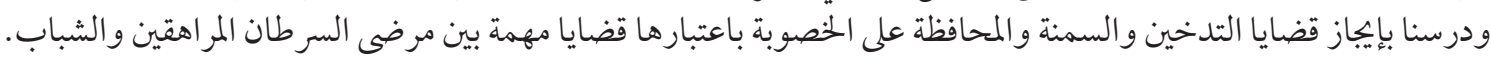

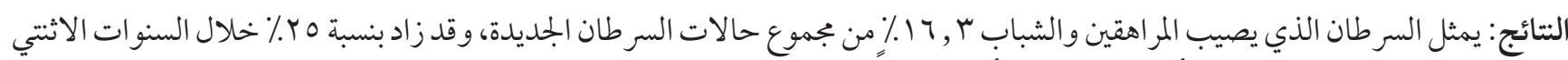

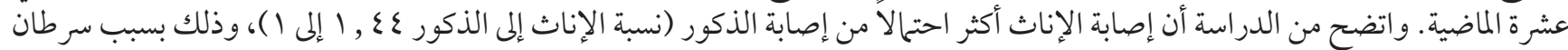

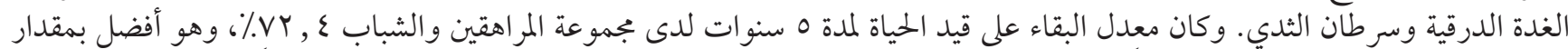

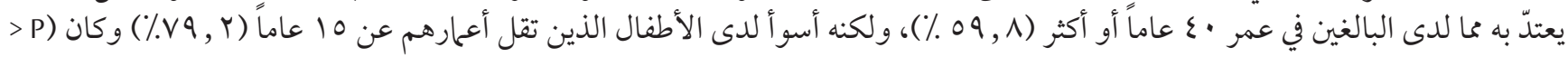
$(\cdot, \cdots)$

الاستنتاج: يمثل السرطان في المر اهقين والشباب نسبة كبيرة ومتنامية من تشخيصات الأورام. وتمّّ الحاجة إلى إنشاء وحدة خخصصة لهم بسبب

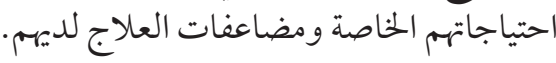

\section{References}

1. Ministry of Health 2014 Report. Available at: http://www.moh.gov.jo/Echobusv3.o/SystemAssets/2docc71d-d935-4d6f-a72c-73d6ocdoa16c.pdf. Accessed 10 March 2018

2. Ferrari A, Bleyer A. Participation of adolescents with cancer in clinical trials. Cancer Treat Rev. 2007 Nov;33(7):603-8. https://doi.org/10.1016/j. ctrv.2006.11.005 PMID:17250970

3. Burke ME, Albritton K, Marina N. Challenges in the recruitment of adolescents and young adults to cancer clinical trials. Cancer. 2007 Dec 1;110(11):2385-93. https://doi.org/10.1002/cncr.2306o PMID:17918260

4. The National Comprehensive Cancer Network guidelines. (https://www.nccn.org/professionals/physician_gls/pdf/aya.pdf, accessed 10 January 2017).

5. Adolescents and young adults with cancer. National Cancer Institute (https://www.cancer.gov/types/aya, accessed 26 February 2018).

6. Butow P, Palmer S, Pai A, Goodenough B, Luckett T, King M. Review of adherence-related issues in adolescents and young adults with cancer. J Clin Oncol. 2010 Nov 10;28(32):4800-9. https://doi.org/10.1200/JCO.2009.22.2802 PMID:20212260

7. Geiger AM, Castellino SM. Delineating the age ranges used to define adolescents and young adults. J Clin Oncol. 2011 Jun 1;29(16):e492-3. https:// doi.org/10.1200/JCO.2011.35.5602 PMID:21482981

8. Bleyer A, Montello M, Budd T, Saxman S. National survival trends of young adults with sarcoma: lack of progress is associated with lack of clinical trial participation. Cancer. 2005 May 1;103(9):1891-7. https://doi.org/10.1002/cncr.20995 PMID:15795902

9. Boissel N, Auclerc MF, Lhéritier V, Perel Y, Thomas X, Leblanc T, et al. Should adolescents with acute lymphoblastic leukemia be treated as old children or young adults? Comparison of the French FRALLE-93 and LALA-94 trials. J Clin Oncol. 2003 Mar 1;21(5):774-80. https://doi.org/10.1200/ JCO.2003.02.053 PMID:12610173

10. 10. Khamly KK, Thursfield VJ, Fay M, Desai J, Toner GC, Choong PF, et al. Gender-specific activity of chemotherapy correlates with outcomes in chemosensitive cancers of young adulthood. Int J Cancer. 2009 Jul 15;125(2):426-31. https://doi.org/10.1002/ijc.24376 PMID:19391136

11. Ferrari A, Thomas D, Franklin AR, Hayes-Lattin BM, Mascarin M, van der Graaf W, et al. Starting an adolescent and young adult program: some success stories and some obstacles to overcome. J Clin Oncol. 2010 Nov 10;28(32):4850-7. https://doi.org/10.1200/JCO.2009.23.8097 PMID:20479411

12. Freyer DR. Transition of care for young adult survivors of childhood and adolescent cancer: rationale and approaches. J Clin Oncol. 2010 Nov 10;28(32):4810-8. https://doi.org/10.1200/JCO.2009.23.4278 PMID:20351333

13. Al-Sayaideh A, Nimri O, Arqoub K, Al-Zaghal M, Halasa W. Cancer incidence in Jordan - 2012. Ministry of Health, Non-Communicable Diseases Directorate, Jordan Cancer Registry; 2012 (http://www.moh.gov.jo/Echobusv3.0/SystemAssets/a05a084b-3781-4979-a217-2184d5d57ede.pdf, accessed 26 February 2018).

14. Korde LA, Partridge AH, Esser M, Lewis S, Simha J, Johnson RH. Breast cancer in young women: research priorities. A report of the young survival coalition research think tank meeting. J Adolesc Young Adult Oncol. 2015 Mar;4(1):34-43. https://doi.org/10.1089/jayao.2014.0049 PMID:26812429

15. Anders CK, Hsu DS, Broadwater G, Acharya CR, Foekens JA, Zhang Y, et al. Young age at diagnosis correlates with worse prognosis and defines a subset of breast cancers with shared patterns of gene expression. J Clin Oncol. 2008 Jul 10;26(20):3324-30. https://doi.org/10.1200/JCO.2007.14.2471 PMID:18612148

16. Collins LC, Marotti JD, Gelber S, Cole K, Ruddy K, Kereakoglow S, et al. Pathologic features and molecular phenotype by patient age in a large cohort of young women with breast cancer. Breast Cancer Res Treat. 2012 Feb;131(3):1061-6. https://doi.org/10.1007/s10549-011-1872-9 PMID:22080245 
17. Hartley MC, McKinley BP, Rogers EA, Kalbaugh CA, Messich HS, Blackhurst DW, et al. Differential expression of prognostic factors and effect on survival in young (< or =40) breast cancer patients: a case-control study. Am Surg. 2006 Dec;72(12):1189-94, discussion 1194-5. PMID:17216817

18. Fernandes-Taylor S, Adesoye T, Bloom JR. Managing psychosocial issues faced by young women with breast cancer at the time of diagnosis and during active treatment. Curr Opin Support Palliat Care. 2015 Sep;9(3):279-84. https://doi.org/10.1097/SPC.00000000000000161 PMID:26164840

19. Foulkes WD. Inherited susceptibility to common cancers. N Engl J Med. 2008 Nov 13;359(20):2143-53. https://doi.org/10.1056/NEJMrao802968 PMID:19005198

20. Chen S, Parmigiani G. Meta-analysis of BRCA1 and BRCA2 penetrance. J Clin Oncol. 2007 Apr 10;25(11):1329-33. https://doi.org/10.1200/ JCO.2006.09.1066 PMID:17416853

21. Mavaddat N, Peock S, Frost D, Ellis S, Platte R, Fineberg E, et al.; EMBRACE. Cancer risks for BRCA1 and BRCA2 mutation carriers: results from prospective analysis of EMBRACE. J Natl Cancer Inst. 2013 Jun 5;105(11):812-22. https://doi.org/10.1093/jnci/djto95 PMID:23628597

22. Robison LL, Armstrong GT, Boice JD, Chow EJ, Davies SM, Donaldson SS, et al. The Childhood Cancer Survivor Study: a National Cancer Institute-supported resource for outcome and intervention research. J Clin Oncol. 2009 May 10;27(14):2308-18. https://doi.org/10.1200/ JCO.2009.22.3339 PMID:19364948

23. Mostoufi-Moab S, Seidel K, Leisenring WM, Armstrong GT, Oeffinger KC, Stovall M, et al. Endocrine abnormalities in aging survivors of childhood cancer: a report from the Childhood Cancer Survivor Study. J Clin Oncol. 2016 Sep 20;34(27):3240-7. https://doi.org/10.1200/JCO.2016.66.6545 PMID:27382091

24. Abughosh S, Wu IH, Hawari F, Peters RJ, Yang M, Crutchley R, et al. Cigarette smoking among Jordanian adults. J Ethn Subst Abuse. 2012;11(2):101-12. https://doi.org/10.1080/15332640.2012.674888 PMID:22679892

25. Khabour OF, Alzoubi KH, Eissenberg T, Mehrotra P, Azab M, Carroll MV, et al. Waterpipe tobacco and cigarette smoking among university students in Jordan. Int J Tuberc Lung Dis. 2012 Jul;16(7):986-92. https://doi.org/10.5588/ijtld.11.0764 PMID:22525279

26. Obeidat SR, Khabour OF, Alzoubi KH, Mahasneh AM, Bibars AR, Khader YS, et al. Prevalence, social acceptance, and awareness of waterpipe smoking among dental university students: a cross sectional survey conducted in Jordan. BMC Res Notes. 2014 11 24;7(1):832. https://doi. org/10.1186/1756-0500-7-832 PMID:25421621

27. Flegal KM, Carroll MD, Ogden CL, Curtin LR. Prevalence and trends in obesity among US adults, 1999-2008. JAMA. 2010 Jan 20;303(3):235-41. https://doi.org/10.1001/jama.2009.2014 PMID:20071471

28. Ogden CL, Carroll MD, Kit BK, Flegal KM. Prevalence of obesity and trends in body mass index among US children and adolescents, $1999-2010$. JAMA. 2012 Feb 1;307(5):483-90. https://doi.org/10.1001/jama.2012.40 PMID:22253364

29. Ogden CL, Carroll MD, Lawman HG, Fryar CD, Kruszon-Moran D, Kit BK, et al. Trends in obesity prevalence among children and adolescents in the United States, 1988-1994 through 2013-2014. JAMA. 2016 Jun 7;315(21):2292-9. https://doi.org/10.1001/jama.2016.6361 PMID:27272581

30. Ajlouni K, Jaddou H, Batieha A. Obesity in Jordan. Int J Obes Relat Metab Disord. 1998 Jul;22(7):624-8. https://doi.org/10.1038/sj.ijo.0800637 PMID:9705020

31. Al Nsour M, Al Kayyali G, Naffa S. Overweight and obesity among Jordanian women and their social determinants. East Mediterr Health J. 2013 Dec;19(12):1014-9. PMID:24684099

32. Khader Y, Batieha A, Ajlouni H, El-Khateeb M, Ajlouni K. Obesity in Jordan: prevalence, associated factors, comorbidities, and change in prevalence over ten years. Metab Syndr Relat Disord. 2008 Jun;6(2):113-20. https://doi.org/10.1089/met.2007.0030 PMID:18510436

33. Wilson CL, Liu W, Yang JJ, Kang G, Ojha RP, Neale GA, et al. Genetic and clinical factors associated with obesity among adult survivors of childhood cancer: a report from the St. Jude Lifetime Cohort. Cancer. 2015 Jul 1;121(13):2262-70. https://doi.org/10.1002/cncr.29153 PMID:25963547

34. Oeffinger KC, Mertens AC, Sklar CA, Yasui Y, Fears T, Stovall M, et al.; Childhood Cancer Survivor Study. Obesity in adult survivors of childhood acute lymphoblastic leukemia: a report from the Childhood Cancer Survivor Study. J Clin Oncol. 2003 Apr 1;21(7):1359-65. https://doi.org/10.1200/ JCO.2003.06.131 PMID:12663727

35. Dietz WH, Robinson TN. Clinical practice. Overweight children and adolescents. N Engl J Med. 2005 May 19;352(20):2100-9. https://doi. org/10.1056/NEJMcp043052 PMID:15901863

36. Hammond RA, Levine R. The economic impact of obesity in the United States. Diabetes Metab Syndr Obes. 2010 08 30;3:285-95. https://doi. org/10.2147/DMSO.S7384 PMID:21437097

37. Wolk A, Gridley G, Svensson M, Nyrén O, McLaughlin JK, Fraumeni JF, et al. A prospective study of obesity and cancer risk (Sweden). Cancer Causes Control. 2001 Jan;12(1):13-21. https://doi.org/10.1023/A:1008995217664 PMID:11227921

38. Calle EE, Rodriguez C, Walker-Thurmond K, Thun MJ. Overweight, obesity, and mortality from cancer in a prospectively studied cohort of U.S. adults. N Engl J Med. 2003 Apr 24;348(17):1625-38. https://doi.org/10.1056/NEJMoa021423 PMID:12711737

39. Pan SY, Johnson KC, Ugnat AM, Wen SW, Mao Y; Canadian Cancer Registries Epidemiology Research Group. Association of obesity and cancer risk in Canada. Am J Epidemiol. 2004 Feb 1;159(3):259-68. https://doi.org/10.1093/aje/kwho41 PMID:14742286

40. World Cancer Research Fund, American Institute for Cancer Research. Food, nutrition, physical activity and the prevention of cancer: global perspective. Washington, DC: AICR; 2007 (https://www.wcrf.org/sites/default/files/Second-Expert-Report.pdf, accessed 26 February 2018)

41. Ewertz M, Jensen MB, Gunnarsdóttir KA, Højris I, Jakobsen EH, Nielsen D, et al. Effect of obesity on prognosis after early-stage breast cancer. J Clin Oncol. 2011 Jan 1;29(1):25-31. https://doi.org/10.1200/JCO.2010.29.7614 PMID:21115856

42. Protani M, Coory M, Martin JH. Effect of obesity on survival of women with breast cancer: systematic review and meta-analysis. Breast Cancer Res Treat. 2010 Oct;123(3):627-35. https://doi.org/10.1007/s10549-010-0990-o PMID:20571870

43. Sinicrope FA, Foster NR, Sargent DJ, O'Connell MJ, Rankin C. Obesity is an independent prognostic variable in colon cancer survivors. Clin Cancer Res. 2010 Mar 15;16(6):1884-93. https://doi.org/10.1158/1078-0432.CCR-09-2636 PMID:20215553

44. Colleoni M, Li S, Gelber RD, Price KN, Coates AS, Castiglione-Gertsch M, et al.; International Breast Cancer Study Group. Relation between chemotherapy dose, oestrogen receptor expression, and body-mass index. Lancet. 2005 Sep 24-30;366(9491):1108-10. https://doi.org/10.1016/So1406736(05)67110-3 PMID:16182899

45. Griggs JJ, Sorbero ME, Lyman GH. Undertreatment of obese women receiving breast cancer chemotherapy. Arch Intern Med. 2005 Jun 
13;165(11):1267-73. https://doi.org/10.1001/archinte.165.11.1267 PMID:15956006

46. Pandita A, Sharma D, Pandita D, Pawar S, Tariq M, Kaul A. Childhood obesity: prevention is better than cure. Diabetes Metab Syndr Obes. 2016 Mar 15;9:83-9. https://doi.org/10.2147/DMSO.S90783 PMID:27042133

47. Griggs JJ, Sabel MS. Obesity and cancer treatment: weighing the evidence. J Clin Oncol. 2008 Sep 1;26(25):4060-2. https://doi.org/10.1200/ JCO.2008.17.4250 PMID:18757320

48. Benedict C, Shuk E, Ford JS. Fertility issues in adolescent and young adult cancer survivors. J Adolesc Young Adult Oncol. 2016 Mar;5(1):48-57. https://doi.org/10.1089/jayao.2015.0024 PMID:26812452

49. Suhag V, Sunita BS, Sarin A, Singh AK, Dashottar S. Fertility preservation in young patients with cancer. South Asian J Cancer. 2015 JulSep;4(3):134-9. https://doi.org/10.4103/2278-330X.173175 PMID:26942145

50. Moore HC, Unger JM, Phillips KA, Boyle F, Hitre E, Porter D, et al.; POEMS/S023o Investigators. Goserelin for ovarian protection during breast-cancer adjuvant chemotherapy. N Engl J Med. 2015 Mar 5;372(10):923-32. https://doi.org/10.1056/NEJMoa1413204 PMID:25738668

51. Nieman CL, Kinahan KE, Yount SE, Rosenbloom SK, Yost KJ, Hahn EA, et al. Fertility preservation and adolescent cancer patients: lessons from adult survivors of childhood cancer and their parents. Cancer Treat Res. 2007;138:201-17. https://doi.org/10.1007/978-0-387-72293-1_15 PMID:18080667

52. Hayes-Lattin B, Mathews-Bradshaw B, Siegel S. Adolescent and young adult oncology training for health professionals: a position statement. J Clin Oncol. 2010 Nov 10;28(32):4858-61. https://doi.org/10.1200/JCO.2010.30.5508 PMID:20823410

53. Schover LR, Brey K, Lichtin A, Lipshultz LI, Jeha S. Oncologists' attitudes and practices regarding banking sperm before cancer treatment. J Clin Oncol. 2002 Apr 1;20(7):1890-7. https://doi.org/10.1200/JCO.2002.07.174 PMID:11919249

54. Achille MA, Rosberger Z, Robitaille R, Lebel S, Gouin JP, Bultz BD, et al. Facilitators and obstacles to sperm banking in young men receiving gonadotoxic chemotherapy for cancer: the perspective of survivors and health care professionals. Hum Reprod. 2006 Dec;21(12):3206-16. https:// doi.org/10.1093/humrep/del307 PMID:16887922

55. Klock SC, Zhang JX, Kazer RR. Fertility preservation for female cancer patients: early clinical experience. Fertil Steril. 2010 Jun;94(1):149-55. https://doi.org/10.1016/j.fertnstert.2009.03.028 PMID:19406395

56. Partridge AH, Gelber S, Peppercorn J, Sampson E, Knudsen K, Laufer M, et al. Web-based survey of fertility issues in young women with breast cancer. J Clin Oncol. 2004 Oct 15;22(20):4174-83. https://doi.org/10.1200/JCO.2004.01.159 PMID:15483028

57. Loren AW, Mangu PB, Beck LN, Brennan L, Magdalinski AJ, Partridge AH, et al.; American Society of Clinical Oncology. Fertility preservation for patients with cancer: American Society of Clinical Oncology clinical practice guideline update. J Clin Oncol. 2013 Jul 1;31(19):2500-10. https://doi. org/10.1200/JCO.2013.49.2678 PMID:23715580

58. Grover NS, Deal AM, Wood WA, Mersereau JE. Young men with cancer experience low referral rates for fertility counseling and sperm banking. J Oncol Pract. 2016 May;12(5):465-71. https://doi.org/10.1200/JOP.2015.010579 PMID:27118159

59. Sheth KR, Sharma V, Helfand BT, Cashy J, Smith K, Hedges JC, et al. Improved fertility preservation care for male patients with cancer after establishment of formalized oncofertility program. J Urol. 2012 Mar;187(3):979-86. https://doi.org/10.1016/j.juro.2011.10.154 PMID:22264454

6o. Shnorhavorian M, Harlan LC, Smith AW, Keegan TH, Lynch CF, Prasad PK, et al.; AYA HOPE Study Collaborative Group. Fertility preservation knowledge, counseling, and actions among adolescent and young adult patients with cancer: a population-based study. Cancer. 2015 Oct 1;121(19):3499-506. https://doi.org/10.1002/cncr.29328 PMID:26214755

61. Shnorhavorian M, Kroon L, Jeffries H, Johnson R. Creating a standardized process to offer the standard of care: continuous process improvement methodology is associated with increased rates of sperm cryopreservation among adolescent and young adult males with cancer. J Pediatr Hematol Oncol. 2012 Nov;34(8):e315-9. https://doi.org/10.1097/MPH.obo13e3182678e3a PMID:22983421 